\title{
Minimal HER1 and HER2 Expressions in CHO and HEK-293 Cells cause them Appropriate Negative Cells for HERs-Related Studies
}

\author{
Abasalt Hosseinzadeh Colagar ${ }^{1}$, Omolbanin Amjadi ${ }^{1}$, Reza Valadan ${ }^{2}$, Alireza Rafiei ${ }^{2 *}$ \\ ${ }^{1}$ Department of Molecular and Cell Biology, Faculty of Basic Sciences, University of Mazandaran, Babolsar, Iran. \\ ${ }^{2}$ Molecular and Cell Biology Research Center, Department of Immunology, Faculty of Medicine, Mazandaran University of Medical Sciences, \\ Sari, Iran.
}

\section{Received: 17 Oct 2013}

Revised : 10 Nov 2013

Accepted: 25 Nov 2013

Corresponding Authors:

Alireza Rafiei

Molecular and Cell Biology Research

Center, Department of Immunology,

Faculty of Medicine, KM 17 Khazarabad

Road, Khazar Sq, Sari, Iran.

Phone: +98-113543614

E-mail: Rafiei1710@gmail.com

\begin{abstract}
Background: Understanding of cellular and molecular mechanisms involved in cell/tumor growth and progression has led to molecular-targeted therapy. HER1 and HER2 are two main oncogenic components of HER-receptor family considered as targets for cancer research and therapy. Reliable results of HERrelated research and targeted therapies dependent upon cell line with known HER expression status. But there are no published studies focusing on determination of HER1 and HER2 receptors expression in CHO and HEK-293 cell lines.

Materials and Methods: Absolute expressions of HER1 and HER2 in CHO, HEK-293, MDA-MB-468 and SKBR3 cells were evaluated using quantitative real-time PCR. Absolute expression quantification was carried out by serial dilution plasmids harboring HER1 and HER2 to extrapolate standard curve.

Results: Real-time PCR amplification was successfully optimized by HER1 and HER2 plasmids with high efficiency and their copy numbers were calculated. The results showed that HER1 was not expressed in CHO and HEK-293 cells but these cells express HER2 up to $9.4 \times 10^{2}$ and $1.1 \times 10^{5}$ copy $/ \mu \mathrm{g}$, respectively. MDAMB-468 and SKBR3 cells express HER1 up to $8.4 \times 10^{5}$ and $9.7 \times 10^{4}$, respectively. In addition, the expression of HER2 is higher on the surface of SKBR3 cell $\left(6.5 \times 10^{6}\right.$ copy/ $\left./ \mu \mathrm{g}\right)$.

Conclusion: Our study provides a proven insight to HER1 and HER2 expression status in CHO, HEK-293, MDA-MB-468 and SKBR3 cells. Heterologous expression of HER1 and HER2 in cell lines is the first step in structural and functional studies. Since HER1 is not expressed in CHO and HEK-293 endogenously, these cells are ideal for HER receptor related studies.
\end{abstract}

Keywords: Real-time PCR; HER1; HER2; Expression; Targeted-therapy; CHO and HEK-293

Please cite this article as: Hosseinzadeh Colagar A, Amjadi O, Valadan R, Rafiei A. Minimal HER1 and HER2 Expressions in CHO and HEK-293 Cells cause them Appropriate Negative Cells for HERs-Related Studies. Res Mol Med. 2013; 1 (3): 6-12.

\section{Introduction}

Human epidermal growth factor receptors (HER) play an important role in proliferation, migration, angiogenesis, and resistance to apoptosis in many cancers (1). HER family is a tyrosine kinase family including four homologous members: HER1, HER2, HER3 and HER4. They share common structure consist of: an extracellular ligand binding domain, a transmembrane domain, and an intracellular tyrosine kinase domain $(2,3)$. The activation of HER receptor depends on ligand binding, dimerization andphosphorylation of downstream adaptor/proteins. HER1 proto-oncogene encodes a $170 \mathrm{kDa}$ transmembrane glycoprotein related not only to breast carcinogenesis (4) but also in colorectal, gastric, glioblastoma, non- small cell lung, head and neck and ovarian cancers (5). Proto-oncogene HER2/neu encodes a $180 \mathrm{kDa}$ tyrosine kinase receptor related to wide variety of human cancers $(6,7)$. Ligand binding promotes HER receptors homo and hetero dimerization and leads to receptors activation, 
subsequently their signaling pathway, Ras/ Raf/ MEK/ ERK and PI3K/ Akt, are triggered. These downstream signaling pathways resulted in cell/tumor growth and metastasis (8). Inhibition of HER1 and HER2 by antiHER agents can down regulate HER-overexpressing cancers (9). According to the potential of these receptors in pathogenesis of a large number of human cancers, these receptors were considered as promising targets for cancer treatment (10).
Cell lines are indefinite sources of homogenous cell population, manifesting their original properties. Human embryonic kidney cells (HEK)-293 is the most common cell line for rapid production and large scale transient expression of recombinant protein (11). Chinese hamster ovary cells $(\mathrm{CHO})$ is a standard expression system with efficient post translational modification for recombinants therapeutic products (12).

Table 1. Oligonucleotide primer sequences used for RT-PCR amplification

\begin{tabular}{lllr}
\hline Name of Gene & Primer Name & Sequences 5' $\rightarrow$ 3' & Nucleotide position \\
\hline \multirow{2}{*}{ Her 1} & $H E R 1 F$ & GCTTGCATTGATAGAAATGG & $3290-3309$ \\
& $H E R 1 R$ & CAGAGGCTGATTGTGATA & $3493-3476$ \\
Her 2 & $H E R 2 F$ & GCTTTGTGGTCATCCAGAA & $2883-2901$ \\
& $H E R 2 R$ & CTCCAGCCCTAGTGTCAG & $3121-3104$ \\
\hline
\end{tabular}

Therefore, these cell lines are proper model system for biopharmaceutical products targeting HER family in cancer study.

Reliable results of HER- targeted therapies dependent upon cell line with known HER expression status. But, there are no published studies focusing on determination of HER1 and HER2 receptors expression in $\mathrm{CHO}$ and HEK-293 cell lines. Immunobloting analysis done by Shi et al (13) implied no EGFR or HER1 expression, while others (14) mentioned low or undetectable expression level of ErbB receptor in CHO cells. In the same way, HER1 and HER2 expression in HEK-293 cells are controversial in different analysis such as Lanteri et al (15) and Xu et al (16). The present study investigated the precise endogenous expression levels of HER1 and HER2 receptors in CHO and HEK-293 cells.

\section{Materials and Methods}

Cell culture

CHO, HEK-293, SKBR3 (HER2 positive control), and MDA-MB-468 (HER1 positive control) cell lines were purchased from Pasteur Institute, Iran. The cells were grown in suspension culture at $37{ }^{\circ} \mathrm{C}$ under $5 \%$ humidified $\mathrm{CO}_{2}$ in bioactive medium RPMI 1640 (PAA, Pasching/ Austria) containing inactivated fetal bovine serum (PAA, Pasching/ Austria), L-glutamine (300mg/l), penicillin (100 U/ mL), and streptomycin $(100 \mu \mathrm{g} / \mathrm{ml})$. The experiments were carried out at cell densities of $3 \times 10^{6}$ cells per milliliter.

\section{RNA isolation and $c D N A$ synthesis}

The total RNA was isolated from $80 \%$ confluent cultured cells by RNeasy Mini Kit (Qiagen, Germany) according to manufactures' instructions. Finally, RNA pellet dissolved in DEPC-treated water.
Concentration and quality of RNA was checked by the absorbance values at $260 \mathrm{~nm}, \mathrm{~A}_{260 / 280}$ and $\mathrm{A}_{260 / 230}$ ratio and confirmed by electrophoresis in $1 \%$ agarose gel. Total RNA $(1 \mu \mathrm{g})$ was subjected to single strand cDNA synthesis using a cDNA synthesis kit (Parstous, Mashhad/ Iran). Briefly, cDNA synthesis was carried out using $200 \mathrm{U}$ MMLV RTase, $2 \mathrm{mM}$ $\mathrm{dNTP}$ mixture and $200 \mathrm{ng} / \mu \mathrm{l}$ random hexamer in a total volume $20 \mu \mathrm{l}$ reaction containing: $10 \mu \mathrm{l} 2 \mathrm{X}$ RT Premix, $2 \mu \mathrm{l}$ random hexamer, $1 \mu \mathrm{g}$ RNA template and $7 \mu \mathrm{l}$ DEPC-treated water.

\section{Quantitative real time $P C R$}

Her 1 or Her 2 gene expression was determined by quantitative real-time polymerase chain reaction (qRT-PCR) using DNA Mastermix SYBR Premix Ex Taq II (Takara, Japan) on an iCycler iQ5 real- time PCR machine (BioRAD, USA). The gene sequences of Her 1 and Her 2 were derived from the NCBI National Center for Biotechnology Information (NCBI) and primers were designed using Allele ID 7.5 software (Table1).

The final reaction volume for Her 1 was $20 \mu \mathrm{l}$ which contains: $10 \mu \mathrm{l}$ Mastermix SYBR Green II (Takara, Japan), 333 pmol forward primer, 285 pmol reverse primer, $2 \mu \mathrm{l}$ cDNA and $6.7 \mu \mathrm{l}$ distilled water. Her 2 amplification was carried out in $20 \mu \mathrm{l}$ reaction including: $10 \mu \mathrm{l}$ Mastermix SYBR Green II (Takara, Japan), 285 pmol forward primer, 333 pmol reverse primer, $2 \mu \mathrm{l}$ cDNA and $6.7 \mu \mathrm{l}$ distilled water. Her 1 gene amplified in 40 cycles including; $95{ }^{\circ} \mathrm{C}$ for 3 $\min , 95{ }^{\circ} \mathrm{C}$ for $10 \mathrm{sec}, 62.7^{\circ} \mathrm{C}$ for $30 \mathrm{sec}$ and $72{ }^{\circ} \mathrm{C}$ for $30 \mathrm{sec}$ and a final extension for $5 \mathrm{~min}$ at $72{ }^{\circ} \mathrm{C}$, followed by a standard melting curve analysis. Amplification of Her 2 is similar to Her 1 except annealing temperature that is $62{ }^{\circ} \mathrm{C}$ in $30 \mathrm{sec}$. Absolute 
quantification was performed by comparing the threshold cycle values $\left(\mathrm{C}_{\mathrm{T}}\right)$ for the samples, with standard curves generated with HER1 and HER2 plasmid DNA.

\section{Plasmid preparation}

To determine the absolute copy number of the receptors; HER 1 and HER2 plasmids and

Escherichia coli Top 10 competent cells were used. HER1 and HER2 plasmids were transformed to $\mathrm{CaCl} 2$ treated E.Coli Top 10 by heat shock method. Then transformed bacteria plated on LB agar containing $100 \mu \mathrm{g} / \mathrm{ml}$ Ampicillin.

Positive colonies were picked and used for plasmid purification. Plasmids were extracted by AccuPrep Plasmid MiniPrep DNA Extraction Kit (Bioneer, South Korea). Purified plasmids were then linearized with Pvu I restriction enzyme (Fermentas, Germany) and run on a $1 \%$ agarose gel. The linear plasmid band was excised from the gel and the DNA extracted to obtain pure linear plasmid DNA by QIAquick Gel Extraction Kit (Qiagen, Germany). This DNA was then quantified by Nanodrop spectrophotometer (WPA, UK).

\section{Absolute quantitative assay}

To evaluate absolute quantitative gene expression, HER1 and HER2 plasmids (Sino biological, China) were used. Serially diluted standards of HER1 and HER2 plasmids with known concentration were used to produce a standard curve. The standard curve revealed a linear relationship between $\mathrm{C}_{\mathrm{T}}$ and initial amount of total RNA or cDNA, so the concentrations were interpolated from standard curves on the basis of $C_{T}$ values (17). Six 10-fold dilutions of HER1 plasmid and eight 10-fold dilutions of HER2 plasmid were prepared for plotting standard curve (Figure 1). The real-time PCR procedures included appropriate positive and negative controls.

\section{Results}

RNA quality of cell lines was evaluated on a $1 \%$ agarose gel electrophoresis. The concentration and purity of the RNA was described by the mean $\mathrm{A}_{260 / 280}$ and $\mathrm{A}_{260 / 230}$ ratio and were on average 1.83 and 1.89, respectively.

RNA isolation was performed from trypsinized cells and $1 \mu \mathrm{g}$ RNA was reverse transcribed to cDNA. Gene copy numbers were calculated by absolute realtime PCR using serially diluted plasmids as standards. For quality control all RNA isolation and cDNA synthesis carried out two times.

The standard curves were analyzed for two properties, the coefficient of correlation $\left(\mathrm{R}^{2}\right)$ and amplification efficiency (E) derived from the slope of standard curve. The standard curves forHER1 ranging from $2.88 \times 10^{9}$ to $2.88 \times 10^{4}$ copies and HER2 ranging from $2.5 \times 10^{9}$ to $2.5 \times 10^{2}$ copies are shown in Figure 1 . The copy numbers of plasmid DNA were calculated using the online calculator provided by the URI Genomics \& Sequencing Center(18). The formula used is: $\left(\right.$ amount $\left.\times 6.022 \times 10^{23}\right) /\left(\right.$ length $\left.\times 1 \times 10^{9} \times 650\right)$, in which amount, is concentration of plasmid in nanogram/microliter, $6.022 \times 10^{23}$ (molecule/mole) is Avogadro's number, length, is full length of plasmid in base pair, 650 (gram/mole) is the average molecular weight of a base pair and $1 \times 10^{9}$ is used for conversion gram to nanogram.

Copy numbers were calculated for 30 nanogram (ng) of HER1 and HER2 plasmid DNA. Both curves were linear in the range tested $\left(\mathrm{R}^{2}>0.99\right)$ by the duplicate reactions. The slopes of the standard curves for HER1 and HER2 were -3.5 and -3.4 , respectively. From the slopes, high amplification efficiencies of 0.91 and 0.96 were determined for HER1 and HER2 in the tested range.
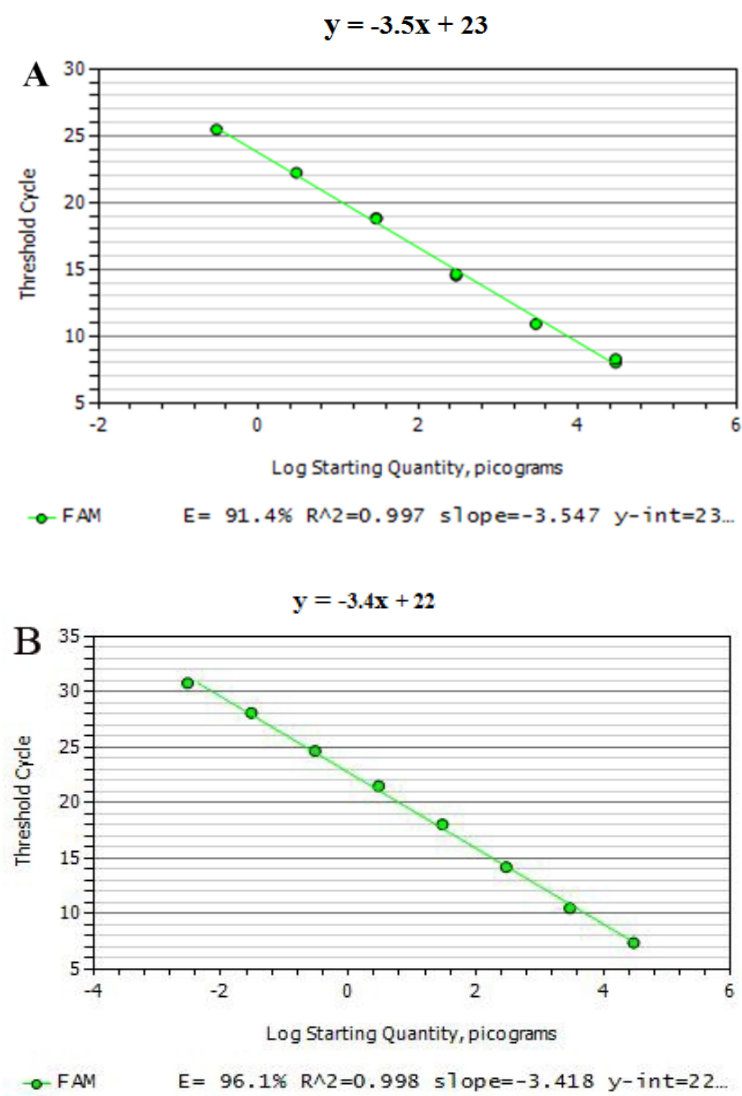

Figure 1. Standard curve for evaluating qPCR optimal assay: Standard curve was plotted with $\mathrm{C}_{\mathrm{T}}$ value against the $\log$ of the starting quantity of standard template for each dilution. $\mathrm{R}^{2}$ value and calculated amplification efficiency were shown below the graph. A. represent HER1 standard curve. B. represent HER2 standard curve.

Our qPCR assay is optimized accurately regarding to 
$\mathrm{R}^{2}>0.99$ showing linear standard curve and efficiency equal to 90-105 representing high amplification efficiency. Therefore, absolute copy numbers of HER1 and HER2 in each cell lines were calculated based on its $\mathrm{C}_{\mathrm{T}}$ value with its plasmid DNA standard curve. The copy numbers of HER1 and HER2 receptors were shown in Table 2.

\section{Discussion}

Precise gene expression profiling by quantitative realtime PCR assay is used to determine HER1 and HER2 expression in CHO and HEK-293 cells. The results demonstrated no endogenous HER1 expression and low level of HER2 expression in these cells. Real-time qPCR provides a fast and reliable technology for gene expression quantification (19).
This sensitive method applies in two convenient ways: absolute and relative. Absolute qPCR assay allows detecting target gene copy numbers based on the standard curve. Plasmid DNA is often used as an external standard for generating standard curve.

As previous studies have confirmed that linear plasmids are more reliable for copy number estimation (20), Pvu I- linearized HER1 and HER2 plasmids were used to measure copy numbers. After ampicillin resistance screening and plasmid purification, these plasmids are brought to create standard curves. The copy numbers of samples were calculated following the qPCR optimizing. Our study showed no Herl amplification in CHO and HEK-293 while HER2 levels were $9.4 \times 10^{2}$ copy/ $\mu \mathrm{g}$ RNA of $\mathrm{CHO}$ and $1.13 \times 10^{5}$ copy/ug RNA of HEK-293, as shown in Table 2.

Table 2. HER1 and HER2 expression in the most common cell lines.

\begin{tabular}{lllllll}
\hline & \multicolumn{3}{c}{ HER 1 } & & & HER 2 \\
\cline { 2 - 3 } \cline { 5 - 6 } Sample name & $\mathbf{C}_{\mathbf{T}}$ & Copy number & & Sample name & $\mathbf{C}_{\mathbf{T}}$ & Copy number \\
\hline CHO & 0 & - & CHO & 34.07 & $9.4075 \times 10^{2}$ \\
HEK- 293 & 0 & - & HEK- 293 & 26.82 & $1.13775 \times 10^{5}$ \\
MDA-MB-468 & 28.73 & $8.4 \times 10^{5}$ & MDA-MB-468 & 29.16 & $1.5 \times 10^{4}$ \\
SKBR-3 & 36.43 & $9.7 \times 10^{4}$ & SKBR-3 & 21.85 & $6.5622 \times 10^{6}$
\end{tabular}

*The copy number of each cell line was calculated in regard to its $\mathrm{C}_{\mathrm{T}}$ and known copy number of HER1 and HER2 plasmids.

According to our results, CHO and HEK-293 don't express HER1 but they express low level of HER2.

Determining HER1 and HER2 expression profiling of CHO and HEK-293 is consequential for many researches. Different results have been reported by Tzahara et al (21), Krug et al (22), Hatakeyama et al (14) and others about HER1 and HER2 expression in CHO. The contradictory results of HER1 and HER2 expression have been reported in HEK-293 (Table 3). The main finding of this study is confirmation and extension previous knowledge about HER1 and HER2 expression by an accurate, sensitive, and fast method.

High levels expression of HER1 $\left(8.4 \times 10^{5} \mathrm{copy} / \mu \mathrm{g}\right)$ in MDA-MB-468 and HER2 $\left(6.5622 \times 10^{6}\right.$ copy/ $\left.\mu \mathrm{g}\right)$ in SKBR3 in our study are concordance to previous studies which reported that MDA-MB-468 and SKBR3 highly expressed HER1 and HER2, respectively (2328). While HER2 expression has not been detected in different studies $(29,30)$, our results showed that MDA-MB-468 expressed HER2 as much as $1.5 \times 10^{4}$ copy $/ \mu$ g. In addition, SKBR 3 cells expressed HER1 up to $9.7 \times 10^{4}$ copy $/ \mu \mathrm{g}$. In other words, eal time PCR is a highly sensitive and accurate method for determining the precise expression of HER 1 and HER2 on the cell surface. HER1 and HER2 activation initiate potent signaling pathways resulted in many key cellular functions, including cell growth, division, migration, adhesion, angiogenesis, and apoptosis (31). These receptors are involved in the pathogenesis of variety of human cancers such as breast, ovarian, bladder, glioblastoma, gastric, lung, and pancreas $(6,7)$.

Since HER1 and HER2 expression profile is a crucial determinant in cancer pathogenesis and cancer related studies, these two main oncogenic components of HER-receptor family considered as targets for biological researches and cancer therapy. Heterologous expression studies are principle part of biological and biomedical researches for analyzing interaction between receptors and their mutations. These studies must be evaluated on cell lines as reliable system model for validation. In addition, many cancerrelated studies such as targeted therapy and drug screening require to right control cell lines. Knowing the precise expression levels of these receptors on cell surface is a fundamental need in the development of any HER- related study.

In the present study, CHO and HEK-293 cells were selected as two most applicable cells used in biomedical and biological studies. Quantitative realtime PCR was performed in order to measure HER1 and HER2 expression levels in these cells. HER1 and 
HER2 expression analysis in these cell lines revealed no copies of HER1 while low copy numbers of HER2 receptor were measured. This is the agreement with the finding of some previous studies used immune precipitation, blotting, and other methods and imply HER1 and HER2 expression pattern in $\mathrm{CHO}$ and HEK-293 cells.

Table 3. Mini review of previous studies about HER1 and HER2 expression in CHO, HEK-293, MDA-MB-468 and SKBR3 cell lines.

\begin{tabular}{|c|c|c|c|c|}
\hline Cell lines & Receptors & Method(s) of Analysis & Results & Reference and Year \\
\hline $\mathrm{CHO}$ & HER 2 & Affinity labeling and co-immunoprecipitation & Low expression (19) & Tzahara et al., 1996 \\
\hline $\mathrm{CHO}$ & EGFR & Affinity labeling and co-immunoprecipitation & No expression (19) & Tzahara et al., 1996 \\
\hline $\mathrm{CHO}$ & $\begin{array}{l}\text { ErbB } \\
\text { receptors }\end{array}$ & Western blot & Low expression ( 21 ) & $\begin{array}{l}\text { Hatakeyama et al., } \\
2004\end{array}$ \\
\hline $\mathrm{CHO}$ & HER1 & Western blot & No expression (22) & Krug et al.,2002 \\
\hline $\mathrm{CHO}$ & EGFR & Immunobotting & No expression (13) & Shi et al., 2000 \\
\hline $\mathrm{CHO}$ & HER 1 & - & No expression (32) & Kim et al., 2002 \\
\hline $\mathrm{CHO}$ & HER2 & $\mathrm{BiFC}$ & Low expression (33) & $\begin{array}{l}\text { Tao and Maruyama, } \\
2008\end{array}$ \\
\hline HEK-293 & HER 1 & BRET & Low expression (34) & Schiffer et al., 2007 \\
\hline HEK-293 & HER1 & - & Expression (35) & Schmidit et al., 2003 \\
\hline HEK-293 & HER 1 & Immunoblotting & No expression (36) & Kancha et al., 2013 \\
\hline HEK-293 & HER2 & - & Low expression (37) & Vermeer et al., 2012 \\
\hline HEK-293 & HER2 & - & Not detected (38) & Kang et al., 2011 \\
\hline HEK-293 & HER2 & - & No expression (16) & Xu et al., 2004 \\
\hline $\begin{array}{l}\text { HEK-293 and } \\
\text { SKBR3 }\end{array}$ & HER2 & Northern blot & $\begin{array}{l}\text { Low expression in HEK-293 and } \\
\text { high expression in SKBR3 (15) }\end{array}$ & Lanteri et al., 2005 \\
\hline HEK-293 & HER2 & - & No expression (39) & Nam et al., 2013 \\
\hline $\begin{array}{l}\text { MDA-MB-468 } \\
\text { and SKBR3 }\end{array}$ & $\begin{array}{l}\text { EGFR and } \\
\text { HER2 }\end{array}$ & Western blot & $\begin{array}{l}\text { High HER } 1 \text { and HER } 2 \text { expression in } \\
\text { MDA-MB- } 468 \text { and SKBR3, } \\
\text { respectively ( } 40 \text { ) }\end{array}$ & Xu et al., 2005 \\
\hline $\begin{array}{l}\text { MDA-MB-468 } \\
\text { and SKBR3 }\end{array}$ & $\begin{array}{l}\text { HER } 1 \text { and } \\
\text { HER2 }\end{array}$ & Western blot & $\begin{array}{l}\text { High HER2 and HER1 in SKBR3 } \\
\text { and MDA-MB-468 (24) }\end{array}$ & Lopez et al., 2008 \\
\hline $\begin{array}{l}\text { MDA-MB-468 } \\
\text { and SKBR3 }\end{array}$ & $\begin{array}{l}\text { HER1 and } \\
\text { HER2 }\end{array}$ & Western blot & $\begin{array}{l}\text { High HER } 1 \text { expression in MDA- } \\
\text { MB-468 and HER1 and } 2 \text { expression } \\
\text { in SKBR3 (30) }\end{array}$ & $\begin{array}{l}\text { Belsches- Jablonski et } \\
\text { al., } 2001\end{array}$ \\
\hline $\begin{array}{l}\text { MDA-MB- } 468 \\
\text { and SKBR3 }\end{array}$ & $\begin{array}{l}\text { HER1 and } \\
\text { HER2 }\end{array}$ & ELISA, CEER method and western blot & $\begin{array}{l}2.0 \times 10^{6} \text { HER } 1 \text { receptors/ cell in } \\
\text { MDA-MB-468 and } 2.5 \times 10^{6} / \text { cell } \\
\text { HER2 receptors in SKBR3 }(28)\end{array}$ & Kim et al., 2011 \\
\hline $\begin{array}{l}\text { MDA-MB-468 } \\
\text { and SKBR3 }\end{array}$ & $\begin{array}{l}\text { HER1 and } \\
\text { HER2 }\end{array}$ & FACS & $\begin{array}{l}1,402,832 \text { HER2 and } 143,599 \text { HER } 1 \\
\text { receptors in SKBR3 and 3,389,807 } \\
\text { HER1 and 1,209 HER2 receptors in } \\
\text { MDA-MB-468 (41) }\end{array}$ & $\begin{array}{l}\text { DeFazio- Eli et al., } \\
2011\end{array}$ \\
\hline SKBR3 & HER2 & $\begin{array}{l}\text { Immunohistochemistry, FISH, Laser- scan } \\
\text { cytometry and quantitative real- time PCR }\end{array}$ & High expression (42) & Xiao et al., 2009 \\
\hline $\begin{array}{l}\text { MDA-MB-468 } \\
\text { and SKBR3 }\end{array}$ & $\begin{array}{l}\text { HER } 1 \text { and } \\
\text { HER } 2\end{array}$ & Immunoblotting & $\begin{array}{l}\text { High HER1 expression in MDA- } \\
\text { MB-468 and High HER2 expression } \\
\text { in SKBR3 (43) }\end{array}$ & $\begin{array}{l}\text { Gunawardane } \text { et al., } \\
2008\end{array}$ \\
\hline MDA-MB-468 & $\begin{array}{l}\text { HER1 and } \\
\text { HER2 }\end{array}$ & Two- color Raman image & $\begin{array}{l}\text { High HER1 and low HER2 } \\
\text { expression (44) }\end{array}$ & Liu et al., 2010 \\
\hline SKBR3 & HER2 & Immunohistochemistry & High expression (45) & Subik et al., 2010 \\
\hline $\begin{array}{l}\text { MDA-MB-468 } \\
\text { and SKBR3 }\end{array}$ & HER2 & Northern blot and western blot & $\begin{array}{l}\text { High expression in SKBR3 but not in } \\
\text { MDA-MB-468 (46) }\end{array}$ & Faltus et al., 2004 \\
\hline
\end{tabular}


HER1 and HER2 are linked to development of many cancers; therefore, they are key targets in functional studies. Such researches need to powerful experimental tools to achieve accurate results. The popularity of cell lines is largely due to their top feathers, making them an ideal model for many biomedical researches especially cancer relatedstudies. The choice of cell line as an in vitro model is the first and important step in cancer research. This indicates the need for more attempts to consider molecular profiles of cell lines.

Taken to gather, this is the first study that quantitatively report HER1 and HER2 expression in CHO and HEK-293 cells. These results provide an important insight to consider HER1 and HER2 expression pattern even in low level for basic and applied studies. Our interest lies in describing right cell lines especially for heterologous expression studies. With respect to data derived from absolute real-time PCR, we suggest that $\mathrm{CHO}$ and HEK-293 are proper cell lines for HER1-related heterologous study while low endogenous expression level of HER2 made these cells suitable for HER receptorrelated research.

\section{References}

1. Bouchalova K, Cizkova M, Cwiertka K, Trojanec R, Friedecky D, Hajduch M. Lapatinib in breast cancer- the predictive significance of HER1 (EGFR), HER2, PTEN and PI3CA genes and lapatinib plasma level assessment. Biomed Pap Med Fac Univ Palacky Olomouc Czech Repub. 2010; 154 (4): 281-8. PMID: 21293538

2. Yarden Y, Ullrich A. Growth factor receptor tyrosine kinases. Annu Rev Biochem. 1988; 57: 443-78. PMID: 3052279

3. Hudis CA. Trastuzumab-mechanism of action and use in clinical practice. N Engl J Med. 2007; 357 (1): 39-51. PMID: 17611206

4.Corzo C, Tusquets I, Salido M, Corominas JM, Bellet M, Suarez M, et al. Characterization of HER1 (c-erbB1) Status in Locally Advanced Breast Cancer Using Fluorescence in situ Hybridization and Immunohistochemistry. Tumor Biol. 2005; 26(1):125-30. PMID: 15741765

5. Klapper LN, Kirschbaum MH, Sela M, Yarden Y. Biochemical and clinical implications of the ErbB/HER signaling network of growth factor receptors. Adv Cancer Res. 2000; 77: 25-79. PMID: 10549355

6. Santarius T, Shipley J, Brewer D, Stratton MR, Cooper CSA. Census of amplified and overexpressed human cancer genes. Nat Rev Cancer. 2010; 10 (1): 59-64. PMID: 20029424

7. Ross JS, Fletcher JA. HER-2/neu (c-erb-B2) gene and protein in breast cancer. Am J Clin Pathol. 1999; 112: S53- 67. PMID: 10396301

8. Yarden Y, Sliwkowski MX. Untangling the ErbB signalling network. Nat Rev Mol Cell Biol. 2001, 2: 127-137. PMID: 11252954

9. Yamaguchi H, Chang SS, Hsu JL, Hung MC. Signaling crosstalk in the resistance to HER family receptor targeted therapy.

\section{Oncogene. 2013. PMID: 23542173}

10. Higgins MJ, Baselga J. Targeted therapies for breast cancer. J Clin Invest. 2011; 121 (10): 3797-803. PMID: 21965336

11. Dietmair S, Hodgson MP, Quek LE, Timmins NE, Gray P, et al. A Multi-Omics Analysis of Recombinant Protein Production in Hek293 Cells. PLoS ONE. 2012; 7 (8): e43394. PMID: 22937046

12. Altamirano C, Berrios J, Vergara M, and Becerra S. Advances in improving mammalian cells metabolism for recombinant protein production. Electron J Biotechnol. 2013; 16 (3).

13. Shi W, Fan H, Shum L, Derynck R. The Tetraspanin Cd9 associates with transmembrane TGF- $\alpha$ and regulates TGF- $\alpha-$ induced EGF receptor activation and cell proliferation. J Cell Biol. 2000; 148(3): 591-602. PMID: 10662783

14. Hatakeyama M, Yumoto N, Yu X, Shirouzu M, Yokoyama S, Konagaya A. Transformation potency of ErbB heterodimer signaling is determined by B-Raf kinase. Oncogene. 2004; 23: 5023- 31. PMID: 15064721

15. Lanteri M, ollier L, Giordanengo V, Lefebvre JC. Designing a HER2/neu promoter to drive $\alpha 1,3$ galactosyltransferase expression for targeted anti- $\alpha \mathrm{Gal}$ antibody-mediated tumor cell killing. Breast Cancer Res. 2005; 7: R487-R494. PMID: 15987454

16. Xu YM, Wang LF, Jia LT, Qui XC, Zhao J, Yu CJ, et al. A caspase-6 and anti-human epidermal growth factor receptor-2 (HER2) antibody chimeric molecule suppresses the growth of HER2-overexpressing tumors. J Immunol. 2004; 173: 61-7. PMID: 15210759

17. Heid CA, Stevens J, Livak KJ, Williams PM. Real time quantitative PCR. Genome Res. 1996; 6: 986-94. PMID: 8908518

18. Staroscik A. Calculator for determining the number of copies of a template. URI Genomics \& Sequencing Center. 2004; 19: 2012 .

19. Burgos JS, Ramirez C, Tenorio R, Sastre I, Bullido MJ. Influence of reagents formulation on real-time PCR parameters. Mol Cell. 2002; 16: 257-60. PMID: 12270266

20. Ball HC, Holmes RK, Londraville RL, Thewissen JGM, Duff RJ. Leptin in whales: validation and measurement of mRNA expression by absolute quantitative real-time PCR. PLoS ONE, 2013; 8 (1): e54277. PMID: 23342116

21. Tzahar E, Waterman H, Chen X, Levkowitz G, Karunagaran D, Lavi S, et al. A hierarchical network of interreceptor interactions determines signal transduction by neu differentiation factor/ neuregulin and epidermal growth factor. Mol Cell Biol. 1996; 16 (10): 5276-87. PMID: 231527

22. Krug AW, Schuster C, Gassner B, et al. Human epidermal growth factor receptor-1 expression renders Chinese hamster ovary cells sensitive to alternative aldosterone signaling. J Biol Chem. 2002; 277:45892- 7. PMID: 12244120

23. Niu G, Carter WB. Human Epidermal Growth Factor Receptor 2 Regulates Angiopoietin-2 Expression in Breast Cancer via AKT and Mitogen-Activated Protein Kinase Pathways. Cancer Res. 2007; 67: (4). PMID: 17308086

24. Emlet DR, Schwartz R, Brown KA, Pollice AA, Smith CA, Shackney SE. HER2 expression as a potential marker for response 
to therapy targeted to the EGFR. Br J Cancer, 2006; 94: 11441153. PMID: 2361260

25. Lattrich C, Juhasz- Boess I, Ortmann O, Treeck O. Detection of an elevated HER2 expression in MCF-7 breast cancer cells overexpressing estrogen receptor $\beta 1$. Oncol Rep. 2008; 19: 811- 7 . PMID: 18288420

26. Rusnak DW, Alligood KJ, Mullin RJ, Spehar GM, ArenasElliott C, Martin AM, et al. Assessment of epidermal growth factor receptor (EGFR, ErbB1) and HER2 (ErbB2) protein expression levels and response to lapatinib (Tykerb®, GW572016) in an expanded panel of human normal and tumor cell lines. Cell Prolif. 2007; 40: 580-94. PMID: 17635524

27. Roda JM, Joshi T, Butchar JP, McAlees JW, Lehman A, Tridandapani S, et al. The activation of natural killer cell effector functions by Cetuximab- coated epidermal growth factor receptorpositive tumor cells is enhanced by cytokines. Clin Cancer Res. 2007; 13: 6419. PMID: 17962339

28. Kim P, Liu X, Lee T, Liu L, Barham R, Kirkland R, et al Highly sensitive proximity mediated immunoassay reveals HER2 status conversion in the circulating tumor cells of metastatic breast cancer patients. Proteo Sci. 2011; 9: 75. PMID: 22172159

29. Lopez D, Sekharam M, Coppola D, Carter WB. Purified human chorionic gonadotripin induces apoptosis in breast cancer. Mol Cancer Ther. 2008; 7 (9): 2837-44. PMID: 18790764

30. Belsches- Jablonski AP, Biscardi JS, Peavy DR, Tice DA, Romney DA, Parsons SJ. Src family kinases and HER2 interactions in human breast cancer cells growth and survival. Oncogene. 2001; 20: 1465-75. PMID: 11313890

31. Yarden Y, Sliwkowski MX. Untangling ErbB signaling network. Nat Rev Mol Cell Biol. 2001; 2: 127-37. PMID: 11252954

32. Kim JH, Satio K, Yokoyama S. Chimeric receptor analyses of the interaction of the ectodomains of ErbB-1 with epidermal growth factor and of those ErbB-4 with neuregulin. Eur J Biochem. 2002; 269(9): 2323-9. PMID: 11985614

33. Tao R.H, Maruyama I.N. All EGF (ErbB) receptors have performed homo- and heterodimeric structures in living cells. $\mathrm{J}$ Cell Sci. 2008; 121(pt19): 3207-17. PMID: 18782861

34. Schiffer HH, Reding EC, Fuhs SR, Lu Q, Piu F, Wong S, et al Pharmacology and signaling properties of Epidermal Growth Factor Receptor isoforms studies by Bioluminescence Resonance Energy Transfer. Mol Pharmacol. 2007; 71(2): 508-18. PMID: 16968809

35. Schimidt MHH, Furnari FB, Cavenee WK, Bogler O Epidermal growth factor receptor signaling intensity determines intercellular protein interactions, ubiqitination and internalization Proc Natl Acad Sci U S A. 2003; 100 (11): 6505-10. PMID: 12734385
36. Kancha RK, Bubnoff NV, Duyster J. Asymmetric kinase dimer formation is crucial for the acticvation of oncogenic EGFRVIII but not for ERBB3 phosphorylation. Cell Commun Signal. 2013; 11: 39. PMID: 23758840

37. Vermeer PD, Bell M, Lee K, Vermeer DW, Wieking BG, Bilal E, et al. ErbB2, EphrinB1, Src kinase and PTPN13 signaling complex regulates MAP kinase signaling in human cancers. PLoS One. 2012; 7 (1): e30447. PMID: 22279592

38. Kang L, Guo Y, Zhang X, Meng J, Wang Z.Y. A positive cross-regulation of HER2 and ER- $\alpha 36$ controls ALDH1 positive breast cancer cells. J Steroid Biochem Mol Biol. 2011; 127 (3-5): 262-8. PMID: 21907803

39. Nam JM, Jeon KH, Kwon H, Lee E, Jun KY, Jin YB, et al. Dithiiranylmethyloxy azaxanthone shows potent anti-tumor activity via suppression of HER2 expression and HER2-mediated signals in HER2-overexpressing breast cancer cells. Eur J Pharm Sci. 2013; 50 (2):181-90. PMID: 23835029

40. Xu H, Yu Y, Marciniak D, Rishi AK, Sarkar FH, Kucuk O, et al. Epidermal growth factor receptor (EGFR)-related protein inhibits multiple members of the EGFR family in colon and breast cancer cells. Mol Cancer Ther. 2005; 4(3): 435-42. PMID: 15767552

41. DeFazio- Eli L, Strommen K, Dao-Pick T, Parry G, Goodman L, Winslow J. Quantitative assays for the measurement of HER1HER2 heterodimerization and phosphorylation in cell lines and breast tumors: applications for diagnostics and targeted drug mechanism of action. Breast Cancer Res. 2011; 13(2):R44. PMID: 21496232

42. Xiao Y, Gao X, Maragh S, Telford WG, Tona A. Cell lines as candidate reference materials for quality control of ERBB2 amplification and expression assays in breast cancer. Clin Chem. 2009; 55(7): 1307-15. PMID: 19443566

43. Gunawardane RN, Rooks A, Nepomuceno RR, Armstrong RC. Broad activity of AC480, a pan- HER inhibitor against HER1 and HER2 expressing tumor cells lines. 2008: 4856.

44. Liu Z, Tabakman S, Sherlock S, Li X, Chen Z, Jiang K, Fan S, Dai H. Multiplexed five- color molecular imaging of cancer cells and tumor tissues with carbon nanotube Raman tags in nearinfrared. Nano Res. 2010; 3 (3): 222- 33. PMID: 3062899

45. Subik K, Lee JF, Baxter L, Strzepek T, Costello D, Crowley P, et al. The expression patterns of ER, PR, HER2, CK5/6, EGFR, Ki-67 and AR by Immunohistochemical analysis in breast cancer cell lines. Breast Cancer (Aucki). 2010; 4: 35-41. PMID: 20697531

46. Faltus T, Yuan J, Zimmer B, Kramer A, Loibl S, Kaufmann M, Strebhardt K. Silencing of the HER2/neu Gene by SiRNA inhibits proliferation and induces apoptosis in HER2/neu-overexpressing breast cancer cells. Neoplasia, 2004; 6 (6): 786-95. PMID: 15720805 